\title{
Comment and Controversy II
}

\section{J. Morgan Kousser}

\section{Are Political Acts Unnatural?}

Written history currently lacks a mainstream. Seeming to bob more violently than usual on numerous cross-currents-QUASSH (Quantitative Social Scientific History), the new labor history, public history, the revival of narrative, etc.-the profession is awash in the flotsam and jetsam of agendas, campaigns, calls to arms, and condemnations. I admit to having contributed to the detritus, but believe it better that the craft be buffeted than that it float lazily and aimlessly or drift into scholarly backwaters. My article on restoring politics to political history, however, was less a manifesto or a critique of previous historical works than it was an attempt to chart more clearly a course which some seemed already to be taking, to warn that the political science party up ahead had run aground on certain shoals, and to describe a possible destination of the journey. I did not mean to ban other trips to other places, and, of course, I have no power to do so. Although I welcome Bourke and DeBats' call to take new bearings before continuing the excursion, I believe that the route that they have plotted fails to take adequate account of certain figurative rapids and eddies. Let me begin by very quickly retracing, less metaphorically, my earlier map. ${ }^{1}$

J. Morgan Kousser is Professor of History and Social Science at the California Institute of Technology. He is the author of The Shaping of Southern Politics (New Haven, 1974).

The author thanks R. Douglas Rivers for forcing him to clarify some of his thoughts and for saving him from some errors and absolves him from further complicity in this reply.

0022-1953/85/030467-14 \$02.50/0

(C) 1985 by The Massachusetts Institute of Technology and the editors of The Journal of Interdisciplinary History.

I Kousser, "Restoring Politics to Political History," Journal of Interdisciplinary History, XII (1982), 569-595; idem, "The Revivalism of Narrative: A Response to Recent Criticisms of Quantitative History," in Social Science History, forthcoming. On the new labor history, see, e.g., David Brody, "The Old Labor History and the New: In Search of An American Working Class," Labor History, XX (1979), I I I-I 26; Robert F. Berkhofer, Jr., "The Two New Histories: Competing Paradigms for Interpreting the American Past," Organization of American Historians, Newsletter (May, I983). On public history, see the vigorous journal, The Public Historian. 
The attempt to relate divisions in society and trends in the socioeconomic structure to those in politics has always been, will remain, and should be one of the chief tasks of American history. Indeed, despite what I view as something of an overconcentration on the subject of the social correlates of electoral behavior during the 1960 s and 1970s, readers of the journals have recently been admonished that "the interrelationship between politics and the social or class structure over the course of American history" constitutes "one of the great neglected themes in American historical thought." Further, they have been assured that, if the new labor historians will but turn some of their attention from the workbench to the political podium, "we may finally begin to bridge the distance between social and political history."2

Far from calling for the independence of political history from the study of other facets of existence, I sought merely to argue that electoral behavior was not the whole of politics-that historians seemed increasingly to be realizing once again that politics includes policy and its consequences as well-and to point out that the structure of political institutions and the actions of political elites (including bureaucrats and judges, as well as elected officials) often make a difference in determining what policies are adopted. Those who seek to examine society through the lens of politics must realize more than they sometimes seem to that that glass distorts. Consequently, the study of how institutions and elites refract society's desires and fail accurately to mirror its characteristics and changes in those traits is necessary for understanding both policy formation in general and in particular instances in the past, as well as for learning how to interpret societal features from the political record. ${ }^{3}$

Bourke, DeBats, McDonald, McCormick, and I may not agree on everything, but all of us wish to place more emphasis than many historians have recently put on the policies which governments adopt, and we tend to see those policies not just as symbolic gestures to an inattentive electorate, but also, at least at

2 Quotes are from Edward Pessen, "Social Structure and Politics in American History," American Historical Review, LXXXVII (1982), I290; Sean Wilentz, "On Class and Politics in Jacksonian America," Reviews in American History, X (1982), 59. Correctives to Pessen's essay by Robert H. Wiebe and Michael B. Katz are in American Historical Review, LXXXVII (1982), I326-I 335 .

3 Cf. Lee Benson, "An Approach to the Scientific Study of Past Public Opinion," in his Toward the Scientific Study of History (Philadelphia, 1972), I 52-1 53 . 
times, as real decisions which significantly affect the distribution of power and welfare in society. If a few copywriters working separately can be said to have launched "a scholarly campaign," we at least all seem to be promoting similar product lines. ${ }^{4}$

Almost any historian, moreover, would acknowledge that Bourke and DeBats' Oregon development company episode is representative of a large number of nineteenth- and even twentieth-century cases, although some would attach less importance to them than Bourke and DeBats (or I) would. Governments made and continue to make a great many important decisions on issues which do not divide citizens on party lines. Contemporary bipartisan "Sunbelt" and "Frostbelt" coalitions in Congress spring immediately to mind. Some choices, such as whether to promote exports, to subsidize agricultural research, or to reduce the dangers of toxic wastes, seem hardly to divide the voters at all. It was only prudent and no doubt not unusual in the mid-nineteenth century to offer stock or directorships in companies which needed franchises from legislatures to influentials of competing political parties, and it is not unknown today for people who do business with governments to contribute to Democrats as well as Republicans.

Certainly the influence of regional or local interest groups ought to be studied. We should not necessarily assume that every issue at the local, state, and national levels splits the polity into the same subsets. Students of city councils or the state or national legislatures who aim to explain the policies which those bodies choose should not arbitrarily exclude undivisive votes from their analyses. As critics of pluralism in political science have been saying for years, it may be as important to consider "non-decisions" as it is to examine decisions. If postbellum Oregonians, for instance, ceased to give automatic assent to pro-development policies, or if such initiatives became associated with one of the two parties, a thoughtful analyst would notice the contrast and

4 In addition to the articles which Paul F. Bourke and Donald A. DeBats cite in "On Restoring Politics to Political History," in this issue, including Richard L. McCormick, "The Party Period and Public Policy: an Exploratory Hypothesis," Journal of American History, LXVI (I979), 279-298, see Terence J. McDonald, "From Economics to Political Economy in the History of Urban Public Policy," Journal of Urban History, VIII (1982), 355-364; idem, "Comment," ibid., 454-462. See also the parallel call for more attention to the provision of urban public services in Jon C. Teaford, "Finis for Tweed and Steffens: Rewriting the History of Urban Rule," Reviews in American History, X (1982), I42-I 47. 
offer an explanation for the change. Although we should never uncritically "recycle old political science" (or old economics or old sociology or old anything else), historians should never fail to exploit valuable insights from any source. ${ }^{5}$

Although recognizing that previous historians came to different conclusions than I did, Bourke and DeBats doubt that my interpretation of the connection between late nineteenth- and early twentieth-century southern black voting strength and the educational benefits that blacks and whites received would be "surprising" to "any mode of historical analysis" or that historians would have needed "any new explanatory model" to arrive at the same result that I did. This view undervalues one of the chief tasks of QUASSH-formulating models explicitly and choosing between them on the grounds of logic, evidence, generalizability, elegance, and simplicity. In the case of southern education, for instance, some historians have averred that paternalistic white politicians altruistically supported black education after disfranchisement, while a whole school of political scientists has insisted that public policies are mere functions of universal societal needs, the satisfaction of which is constrained only by the availability of resources to fund programs. In "Restoring Politics" and in a less theoretical companion piece, I sought to bring these and other largely implicit models to consciousness, to reason about them, and to examine some evidence relating to them. Because these and related models are neither so obvious nor so simple as Bourke and DeBats imply, and because stating them formally may aid other historians of governmental policies, I offer a series of explicit models. ${ }^{6}$

5 Peter Bachrach, The Theory of Democratic Elitism: A Critique (Lanham, Md., 1970). Cf. Ballard C. Campbell's decision, conventional in legislative roll call studies, to delete from his analysis non-divisive votes in his Representative Democracy: Public Policy and Midwestern Legislatures in the Late Nineteenth Century (Cambridge, Mass., 1980), 207.

6 For an example of the paternalistic thesis, see, in addition to the works cited in my earlier article, H. Leon Prather, Sr., Resurgent Politics and Educational Progressivism in the New South: North Carolina, 1890-1913 (Madison, N.J., I979); Dewey W. Grantham, in "The Contours of Southern Progressivism," American Historical Review, LXXXVI (I98 I), IO5O, asserts that the southern Progressive educational campaigns were motivated by reformers' interests in "social order, efficiency, and development as well as in social justice," presumably for blacks as well as whites. Kousser, "Progressivism for MiddleClass Whites Only: The Distribution of Taxation and Expenditures for Education in North Carolina, I880-1910," Journal of Southern History, XLVI (I980), I69-194. 
The Social Determinist model might be expressed, in regression analytic terms, as:

(I) $Y_{j}=\sum_{i=1}^{n} b_{i j} X_{i j}+c_{j} Z_{j}+U_{j}$;

where $i$ indexes an individual's characteristics;

$j$ indexes each individual;

$Y$ is a measure of government outputs received by $j^{\text {th }}$ individual;

$X_{1}, \ldots, X_{n}$ are socioeconomic traits of each individual;

$Z_{j}=\left\{\begin{array}{l}1 \text { if the individual performs some political act, } \\ \text { such as voting; } \\ 0 \text { otherwise; }\end{array}\right.$

$b_{i j}$ and $c_{i j}$ are coefficients to be estimated; and

$U_{j}=$ an error term, which is assumed to have

whatever desirable properties are needed.

The social determinist hypothesis is that $c_{j}=0$.

Equations such as (I) can be changed to group models by conceiving of $j$ as an index, not for individuals, but for each group, such as blacks and whites or rich and poor. Analysts concerned with the relative rather than the absolute level of benefits received by each individual or group may replace $Y_{j}$ by $\left(Y_{j} / \Sigma_{j=1}^{\prime} Y_{j}\right)$. Different assumptions about the error term or the availability of different types of data for the dependent variable might dictate the use of nonlinear rather than linear estimation techniques. Models containing interaction terms or allowing more than two values for $Z_{j}$-for instance, abstention as well as voting for another party-could also be considered in this and the succeeding discussion.

A Pure Electoral model might substitute $\left(Y_{j} / \Sigma Y_{j}\right)$ for $Y_{j}$ in equation (I) above, treat $j$ as indexing groups, and be expressed as the hypothesis that

$$
\begin{aligned}
& c_{j}=\frac{Y_{j}}{\sum_{j=1}^{I} Y_{j}} \\
& b_{i, j}=0 .
\end{aligned}
$$


That is, each group gets the same proportion of benefits as its proportion of votes.

These polar cases only begin to suggest possible models. Consider four variations of a threshold model:

$$
\text { (2) } \frac{Y_{j}}{\sum Y_{j}}=\sum b_{i j} X_{i j}+D_{j} \frac{Z_{j}}{\sum_{j=1}^{I} Z_{j}}+U_{j} \text {; }
$$

where $D_{j}$ is a dummy variable, and all of the other variables are as defined above. Then a Winner Take All model expresses the view that

$$
D_{j}=\left\{\begin{array}{l}
1 \text { if the party preferred by group } j \text { wins; } \\
0 \text { otherwise. }
\end{array}\right.
$$

An instance would be an at-large electoral scheme in which voting is racially polarized and in which blacks are in a minority. In that case, they would elect no representatives. If, however, blacks composed part of a winning coalition, they could be expected to be rewarded with jobs and/or services, according to this model, approximately in proportion to their percentage in the population.

A Large Groups Divide the Pie model says that

$$
D_{j}=\left\{\begin{array}{l}
1 \text { if the group's proportion of votes is above some } \\
\text { threshold, say, } 20 \% ; \\
0 \text { otherwise. }
\end{array}\right.
$$

Further, instead of $\left(Z_{j} / \Sigma_{j=1}^{J} Z_{j}\right)$ in equation (2), we substitute $\left[Z_{j} /\left(\sum_{j=1}^{J} Z_{j}-\sum_{s=1}^{S} Z_{s}\right)\right]$, where $Z_{s}$ represents the small subgroups of the population. Since small subgroups, in this view, get left out of any benefits, the denominator should equal only the sums of the larger groups, instead of all the groups. For example, an ethnic group or a labor union might obtain some representation in appointive offices or on an electoral ticket if and only if they comprised a fifth or more of the voters.

A third variation would replace $Z_{j}$ in equation (2) by $\left(Z_{j} / \Sigma Z_{j}\right)$. Now define $\left[\left(V_{1_{j}}-V_{2_{j}}\right) /\left(\sum_{k=1}^{K} V_{k j}\right)\right]$ as the margin, in percentage terms, between the top two contending political parties or candidates. A Balance of Power model would state that

$$
D_{j}\left\{\begin{array}{l}
\geq 1 \text { if }\left(Z_{j} / \Sigma Z_{j}\right)>\left(V_{1 j}-V_{2 j} / \Sigma V_{k j}\right) \\
=0 \text { otherwise. }
\end{array}\right.
$$

Formulating the model in this explicit fashion has the advantage that it makes clear that additional assumptions are needed. For 
instance, the party or candidate which wins must be able to set the relevant governmental policy, and only a few groups-perhaps only one group-can play the balance of power strategy for there to be a determinative outcome. If no group has a majority and all groups adopt this strategy and vote at the same time, then each and none provides the crucial votes, and the payoffs of each are unpredictable.

A fourth theory, the Good Will model, treats $D_{j}$ in equation (2) as a dictator, and argues that

$D_{j}\left\{\begin{array}{l}\geq 1 \text { if the leader has good will toward group } j, \\ =0 \text { otherwise. }\end{array}\right.$

Some variation of this model may underlie the "progressivepaternalist" view of early twentieth century southern educational history.

A User Fee model may be captured in the following equation:

(3) $\frac{Y_{j}}{\sum Y_{j}}=B \frac{X_{m}}{\sum_{m=1}^{M} X_{m}}+U_{j}$,

where $X_{m}=$ the amount of taxes paid by group $j$; the other variables have already been defined. This allocation theory ("You get what you pay for") is the one which southern governments appear to have adopted for educational expenditures shortly after blacks were disfranchised. Other models of allocation rules might be defined analogously. Consider a Redistribution model:

(4) $\frac{Y_{j}}{\sum Y_{j}}=B \frac{X_{m}}{\sum_{m=1}^{M} X_{m}} X_{r}+U_{j}$

where $X_{m}=$ the income of all individuals in group $j$, $X_{r}=$ a redistribution rule;

the other variables have already been explained. If $X_{r}$ really is redistributive, then $B<0$, or the richer the group, the smaller the proportion of benefits it receives.

Other models and tests of them in particular cases could be conceived. Formulating and evaluating such models explicitly should be one of the chief immediate tasks of the developing historical literature on policy and institutional rules. That the educational example which I investigated briefly in "Restoring Politics" stimulated these formalizations provides some excuse for considering that example. 
But there are other reasons besides furthering an ongoing academic discussion for paying attention to a particular issue or set of issues; reflection on Bourke and DeBats' discussion suggests that it may be useful to try to categorize and evaluate some of these criteria. The first, used unreflectively by older style political historians, might be termed the platform rule: those issues which politicians discussed are the important ones. Because issue stances may be symbolic or so compromised or ambiguous as to be meaningless, or because they may aim only at swing voters, while ignoring the particular politicos' safe base of voters as well as those obstinately committed to their opponents, this is much too simple a model. Nevertheless, platforms and speeches, critically examined, still play a necessary role in any model of a voter's decision calculus. If everyone were talking about secession and slavery in I 860, could northern voters have really ignored such issues and voted on the basis of the tariff or of liquor and antipopery?

The second is the conflict criterion: the issues which split the voters and/or their representatives must be assumed to be the crucial ones. Yet, as pointed out earlier, this rule may exclude matters which are significant according to other standards. Moreover, some historians may prefer studying what united, rather than what divided people, and on what ultimate basis can we say that they are wrong?

A third formula I have designated the law of effects: study those policies which had large impacts on politics or society. This principle presents two difficulties. The consequences of a policy may be difficult to discern, for the condition in question might have been produced by other causes, or the voters might not have clearly expressed their intention that the policy be adopted; concentrating on it would therefore necessarily disconnect electoral politics from policy formation. An example of the former is the double-digit inflation in the United States in 1980 , which voters blamed on President Jimmy Carter, but which was produced in large measure by a rise in oil prices over which he could not possibly have exerted much control; the case of United States escalation of the war in Vietnam by erstwhile "peace candidate" President Lyndon B. Johnson in 1965 illustrates the latter. Nonetheless, since many policies do have relatively clear consequences and are demonstrably related to electoral mandates, the impact rule remains the basic guide for choosing what to analyze. 
The fourth or historicist standard focuses on the origins and development of policies which subsequently have important effects, such as the question of whether the framers of the Fourteenth Amendment meant to outlaw school segregation. This formula obviously runs the risk of elevating to major status concerns which were minor at the time.

Fifth, closely connected, and suffering from the same difficulty, is the socially interesting facts rule, which allows one to concentrate on any policies which the analyst thinks significant, whether they received much attention in the electoral or legislative arenas or not. Prototypes of this criterion might include nineteenth-century abortion or obscenity laws or the myriad special incorporation laws such as Bourke and DeBats' Oregon development company example. Since none of these criteria can command universal support, and since some relate policy less strongly to electoral politics or to the study of society or the economy than others do, the closeness of the connection between the developing historical study of policy and the other political and extra-political realms will depend on the number of instances in which historians employ each rule.

In their speculative remarks Bourke and DeBats suggest that in nineteenth-century America, before the development of large professional bureaucracies, the decline in political participation, and the increase in the power of formally organized interest groups, the connection between societal pressure groups and policy outcomes was closer than it has been recently. Yet the current disconnection between electoral pressures and policy is not as great as Bourke and DeBats imply, and nineteenth-century politics was less "distinctive" than they maintain. California's Proposition I 3 and its counterparts in other states have rolled back taxes and governmental services rapidly and directly. The environmental movement has greatly increased the attention which public authorities must pay to pollution, atomic power plant dangers, and unplanned growth. Nuclear freeze campaigns have emboldened politicians to attempt to slow the momentum of the arms race. It would be a considerable exaggeration to claim, furthermore, that efforts to give controversial moral preferences the force of law have entirely dissipated, and it is at least arguable that politics is no more secular now that it was a century or more ago. Consider the contemporary crusades of the anti-abortionists, 
the school prayer enthusiasts, and the opponents of "obscenity," all of which have nineteenth-century parallels.

This is not to say that Bourke and DeBats are wrong about the increasing complexity of the policy process. It was precisely because of the comparative simplicity, openness, and decentralized nature of nineteenth-century American government that I urged focusing on that period as a means of beginning to understand more deeply the connections between electoral politics and policy. Nevertheless, I would take exception if, by stating that "political acts" were "indistinguishable" from those which citizens performed in non-political roles, Bourke and DeBats are contending that the political structure and the actions of political elites did not even then affect the way in which the desires of social groups were translated into governmental policies.

To be sure, abolition, temperance, Sabbatarian, anti-Catholic, and other movements originated outside of politics. But they inevitably had to change when they entered politics. It was one thing to urge voluntary moral reform on individuals. Freely emancipating one's slaves or encouraging others to do so, swearing off alcohol, abstaining from Sunday work, and converting to active Protestantism involved only peer pressure, not legal coercion. But when reformers sought to employ governmental power to compel others to act, they encountered institutional impediments to action, temporizing politicians who feared to alienate any substantial number of voters, and implacable resistance from other groups (slaveholders most importantly, but also immigrants whose cultural norms and traditions allowed drinking, honored "European" Sundays, and favored parochial schools). Federalism and constitutional restraints reduced abolition to free soilism, politicians' cautiousness often watered down prohibition into license laws, courts sometimes banned assaults on "natural rights," as in the I855 Wynehamer case in New York, and the difficulties of enforcing compliance with Sunday "blue laws" led to their practical abandonment in many large cities. If moral reformers sought the transfiguration of society through political means, they soon found that the political process transfigured the nature and tactics of reform as well. ${ }^{7}$

7 In his recent fine summary of historical scholarship on legislatures, Joel H. Silbey, who generally adheres to the ethnocultural approach, nevertheless emphasizes the marked 
Although I agree with Bourke and DeBats that the role of the state has grown, in fits and starts, throughout American history, and that policymaking has become more complicated, continuous, and centralized, their assertions that American politics has become more secular, less responsive to electoral currents, and less rooted in "the structures of social relations," seems dubious. As examples of pragmatic, often nonpartisan, amoral pressure-group politics, it would be difficult to improve upon the nineteenth-century battles over tariff schedules or rivers and harbors, transportation subsidies, and banking laws, as, indeed, their Oregon example shows. To contend that the Progressive Era, with its prohibition and woman suffrage movements, its pervasive concern with corruption, its war to "make the world safe for democracy," and its coercive Americanization drives, exhibited fewer moral concerns than did Gilded Age politics is questionable. To assert that the class politics of the New Deal and Fair Deal failed to touch deep roots in the social structure would badly distort the historical evidence. To maintain that the civil rights and anti-Vietnam War struggles had no moral overtones would invite sarcasm. To argue that, in their statements and actions, politicians from competing parties differed from each other more sharply and honestly and on a greater range of issues in the last century than they do today is to substitute nostalgia for analysis. And it is surely the case that never in American history have we had two consecutive presidents who exposed their religious professions more regularly to the electorate than have Carter and Ronald Reagan. If revivalistic politics ever died, it has recently been born again. Even economic management has become less a matter of technical competence than of apparently unshakable beliefs in what is often referred to as the supply-side "religion" or, in its competing faith, the gospel of John Maynard Keynes, or, in what is doubtless at the core of these belief systems, the credos that government policies should primarily benefit the rich or, conversely, aid the rest of us. ${ }^{8}$

effect of institutions on policy. "Legislative voting behavior," he remarks, "is not the ritualistic recording of decisions made elsewhere." See his "Delegates Fresh from the People': American Congressional and Legislative Behavior," Journal of Interdisciplinary History, XII (1983), 604.

8 On the progressives, McCormick, From Realignment to Reform: Political Change in New York State, 1893-1910 (Ithaca, 198I); idem, "Party Period and Public Policy"; idem, "The 
Empirical disputes about the degree of difference between nineteenth- and twentieth-century American politics aside, Bourke and DeBats seem to me to beg three theoretical questions in their basic approach to the social analysis of politics-an approach which is best encapsulated in their phrase about "the politics of natural settings and natural groupings." First, to speak in such terms is to assume, a priori, that organized, conventional politics is somehow unnatural and epiphenomenal per se. Yet to contend that a political group is necessarily less natural than a church, a lodge, a union, or a social class, each of which may include individuals who have vastly different experiences, tastes, and perceived self-interests, is to assert a very strong unstated theory that allows one to distinguish the real from the unreal. Was Tammany Hall less important to its members' lives than the Congregational church was to its parishioners? Was a man's ethnic identity more important to him than his partisan affiliation? Should such questions be finessed with a phrase?

Second, even assuming, for the sake of argument, that social groups are more genuine than political groups, the question of which divisions of society are essential and which are artificial is heavily contested. If forced to choose, what allegiance would Bourke and DeBats announce- - hard Marxist economic determinism, soft Marxist cultural hegemony, Hegelian idealism, or Bensonian "Marxist" ethnoculturalism? And how, apart from a leap of faith, would they justify their creed? To Beardeans as well as to such young Marxists as Wilentz, classes, defined for the first by the nature of their property and for the second by their relation to the means of production, are real, and the ethnoculturalists' history is of the consensus variety because it charts conflict only between superficially different aggregates of people. Since Wilentz seems to believe it wrong in principle to try to distinguish be-

\footnotetext{
Discovery that Business Corrupts Politics: A Reappraisal of The Origins of Progressivism," American Historical Review, LXXXVI (1981), 247-274; Daniel T. Rodgers, "In Search of Progressivism," Reviews in American History, X (1982), I13-I32. On the growing party splits in Congress, see, e.g., Keith Poole and Howard Rosenthal, "The Polarization of American Politics," Social Science Working Paper \# 476 , California Institute of Technology (April, 1983). The theological pretensions of Reaganomics appear in George Gilder, Wealth and Poverty (New York, 1981), and the mundane reality in Frances Fox Piven and Richard A. Cloward, The New Class War: Reagan's Attack on the Welfare State and Its Consequences (New York, 1982).
} 
tween cultural and class interpretations or to argue from the only available evidence on how large numbers of men behaved politically-aggregated census and voting data-the rival Marxist and ethnocultural schools of the social history of politics disagree not only on questions about the nature of society, but also in their fundamental epistemological stances. Such disputes create apparently unseen difficulties for Bourke and DeBats. ${ }^{9}$

Third, even if we knew that social groups were natural and which ones of them were, it would not necessarily follow that they were natural in politics, and, a fortiori, on every level of politics. In the first half of the twentieth century, most white Baptists and Episcopalians in the South appear to have voted their differing religions on the issue of prohibition, their common race on that of segregation, and their somewhat overlapping classes on economic matters. Nineteenth-century factory workers and owners often stood together along industry lines on the subject of the tariff, split on ethnic or religious bases on liquor, divided into class groups on questions of maximum hours or legalizing labor unions, and coalesced on a sectional basis on slavery and secession. Which groupings in these shifting kaleidoscopes were natural?

Some students of policy outputs in political science proved to their own satisfaction that electoral politics had so little effect on policies that an analyst of laws and regulations could safely ignore voters and elections. In "Restoring Politics to Political History," I disagreed with that view, and argued that their work was theoretically sterile and methodologically flawed. That my critique of this position should be taken as a call for a research agenda which splits off the social or economic analysis of politics from the study of policy therefore seems ironic. On the contrary, I believe that we all are, or should be, social analysts of politics, economic analysts of politics, as well as political analysts of politics. But if political institutions and the actions of political elites

9 Benson, "Group Cohesion and Social and Ideological Conflict: A Critique of Some Marxian and Tocquevillian Theories," American Behavioral Scientist, XVI (1973), 74 I-767; idem, "Marx's General and Middle-Range Theories of Social Conflict," in Robert K. Merton et al. (eds.), Qualitative and Quantitative Social Research: Papers in Honor of Paul F. Lazarsfeld (New York, I979), I 89-209. Wilentz, "Class and Politics," 45-63. 
are ignored or treated as a black box, complete with pinhole and film, which merely records without distortion what is before it when the opening is periodically uncovered, we will neither obtain accurate pictures of society nor learn much about the process of policy development. 